\title{
Interstitial Lung Disease in Systemic Lupus Erythematosus
}

\author{
Sistemik Lupus Eritematozusta Interstisyel Akciğer Hastalığı
}

Gina Amanda, Prima Belia Fathana, Dianiati Kusumo Sutoyo

\begin{abstract}
Connective tissue disease (CTD) is one of the etiologies of known-cause interstitial lung disease (ILD) that is frequently found with systemic sclerosis, rheumatoid arthritis, mixed-CTD and Siögren syndrome, but which occurs rarely in systemic lupus erythematosus (SLE) patients. A diagnosis of ILD in SLE can be challenging, as the physician should first exclude other pulmonary involvements, including airway disorders, pulmonary infection and vascular abnormality. The management of ILD in SLE and other CTDs patients includes corticosteroid and other immunosuppressive medications. Here we report on two ILD in SLE cases: in one case, ILD was the first sign of SLE; and in another, ILD appeared after the diagnosis of SLE had been established.
\end{abstract}

Key words: Connective tissue disease, interstitial lung disease, systemic lupus erythematosus.

\section{Özet}

Nedeni bilinen interstisiyel akciğer hastalıklarının (IAH) etyolojilerinden birisi de bağ dokusu hastalıkları (BDH)'dır. Nedeni bilinen IAH'ya yol açana BDH arasında, sistemik skleroz, romatoid artrit, miks bağ dokusu hastalıkları ve Sjögren sendromu sıklıkla bulunmaktadır. Ancak sistemik lupus eritematozus (SLE) hastalarında bu durum nadiren görülür. SLE'de IAH tanısı koymak zordur. Hava yolu hastalıkları, pulmoner infeksiyon ve vasküler anormallikler gibi diğer pulmoner tutulumlar öncelikle ekarte edilmelidir. SLE de ve diğer BDH olan İAH hastalarının tedavisinde kortikosteroidler ve diğer immünsüpressif ilaçlar kullanilır. Burada IAH olan iki SLE olgusu sunulmaktadır. Bir olguda SLE'nin ilk bulgusu IAH idi, diğer olguda SLE tanısından sonra İAH görüldü.

Anahtar Sözcükler: Konnektif doku hastalıkları, interstisyel akciğer hastalığı, sistemik lupus eritematozus.

Department of Pulmonology and Respiratory Medicine, Faculty of Medicine Universitas Indonesia, Persahabatan Hospital, Jakarta, Endonezya Üniversitesi Tıp Fakültesi, Persahabatan Hastanesi, Indonesia

Pulmonoloji ve solunum Tıbbi AD, Endonezya

Submitted (Başvuru tarihi): 09.01.2019 Accepted (Kabul tarihi): 24.04.2019

Correspondence (iletişim): Gina Amanda, Department of Pulmonology and Respiratory Medicine, Faculty of Medicine Universitas Indonesia, Persahabatan Hospital, Jakarta, Indonesia

e-mail: gina amanda@ymail.com 
Connective tissue disease (CTD) is a complex autoimmune disorder including systemic lupus erythematosus (SLE), rheumatoid arthritis, systemic sclerosis, mixed-CTD, Sjögren syndrome, polymyositis and dermatomyositis, and others. CTD may affect many organs, one of which is the respiratory system, including the airways, parenchyma, vascular, pleura and respiratory muscles (1). Interstitial lung disease (ILD) is one of the pulmonary manifestations that may present in CTD, and can increase morbidity and mortality in affected patients (2-4). In SLE cases, the occurrence of ILD is unusual. While SLE is the most common CTD in the population, it is only seen in $1-15 \%$ of SLE patients and is related to long-standing disease. This is the reason why the diagnosis of ILD-related SLE is a challenge, since it is usually misdiagnosed with other pulmonary involvements in SLE (1). Here, we report on two cases of ILD in SLE patients.

\section{CASE}

Case 1: A 59-year-old woman was admitted to our clinic complaining of shortness of breath for 4 months and general weakness. Based on these complaints, the patient had been diagnosed with pulmonary tuberculosis (TB) by another physician and treated with anti-TB drugs for about 3 months. Prior to the start of TB treatment, smears of acid-fast bacilli (AFB) sputum were examined and the results were negative. Since there was no improvement in clinical appearance and or chest x-ray findings, the patient was referred to our hospital. The patient had no history of occupational exposure and was a non-smoker. Upon physical examination, the patient was found to be in a moderate general condition. Respiratory rate was 24 breaths per minute with an oxygen saturation of $98 \%$ in room air. Posterior-bibasilar crackles were detected upon pulmonary auscultation, and we also noted that she has a mechanic's hands and evidence of Raynaud's phenomenon in her extremities. A high-resolution computed tomography (HRCT) of the thorax revealed a non-specific interstitial pneumonia (NSIP) pattern (Figure 1). Based on the clinical signs and the HRCT imaging, a diagnosis of ILD-related CTD was suspected. An autoimmune serology test was carried out for confirmation. The anti-nuclear antibody (ANA) test was positive and anti-doublestranded (ds)-DNA antibody was $>150 \mathrm{U} / \mathrm{ml}$ (positive). Specific auto-antibodies tests were also performed, revealing positive anti-Ro-52 and anti-SSA auto-antibodies. As a result of these findings, we referred her to the internist, and a diagnosis of SLE was established. We also carried out a diffusing capacity test of the lungs for carbon monoxide (DLCO) and the result was 35\%. The patient was treated with methylprednisolone and mycophenolic acid (Myfortic $\left.{ }^{\circledR}\right) 180 \mathrm{mg}$ bid.

Case 2: A 23-year-old female was referred from the internal medicine clinic with exertional dyspnea. She had been diagnosed SLE one year previously, and had been treated with corticosteroid (CS) and the immunosuppressive sparing agent mycophenolate mofetil (Cellcept $\left.{ }^{\circledR}\right)$. After 3 months of treatment, the patient ceased taking the medication of her own volition. By the end of three months, her condition had deteriorated, and so she restarted treatment again. At that time, the internist prescribed azathioprine, which she had been taking for 5 months at the time of admittance to our clinic.

A physical examination revealed a moderate general appearance, a respiratory rate of 20 breaths per minute and an oxygen saturation of $96 \%$ in room air. She looked pale and had anemic conjunctiva. Late inspiratory crackles were heard upon pulmonary auscultation, and edemas were noted in the lower extremities. An HRCT scan of the thorax revealed ground-glass opacity with traction bronchiectasis in the bilateral lung fields (Figure 2a). AFB smears of the sputum were checked and the results were negative. A blood hemogram revealed hemoglobin of $8.2 \mathrm{gr} / \mathrm{dl}$. An autoimmune serology test showed positive of ANA, ds-DNA, nucleosomes, histones, Ro-52 and SSA antibodies. The patient was diagnosed with ILD-related SLE. A spirometry test resulted in 22.5\% forced vital capacity (FVC) and $23.6 \%$ forced expiratory volume in 1 second. The patient was treated with CS and Cellcept ${ }^{\circledR} 1000$ mg bid. One month after treatment the patient showed clinical improvement, and six months later, an HRCT of the thorax was carried out for re-evaluation, and further improvement was noted (Figure 2b).

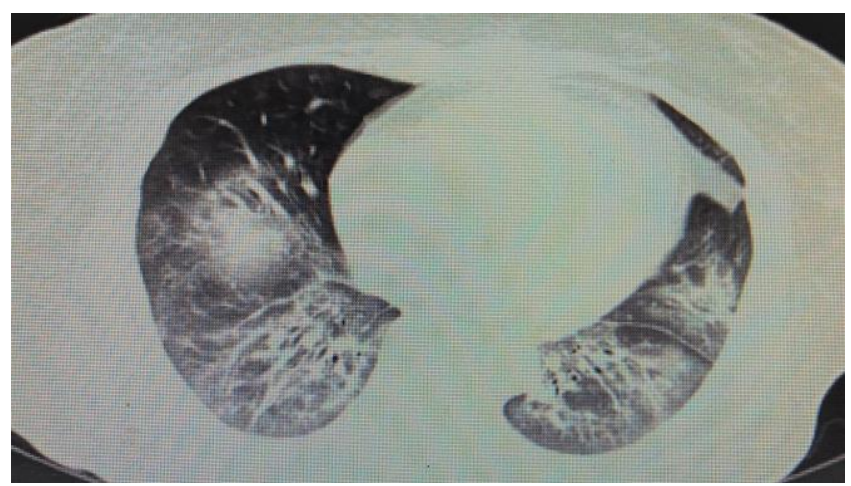

Figure 1: HRCT of the thorax showed a non-specific interstitial pneumonia pattern 


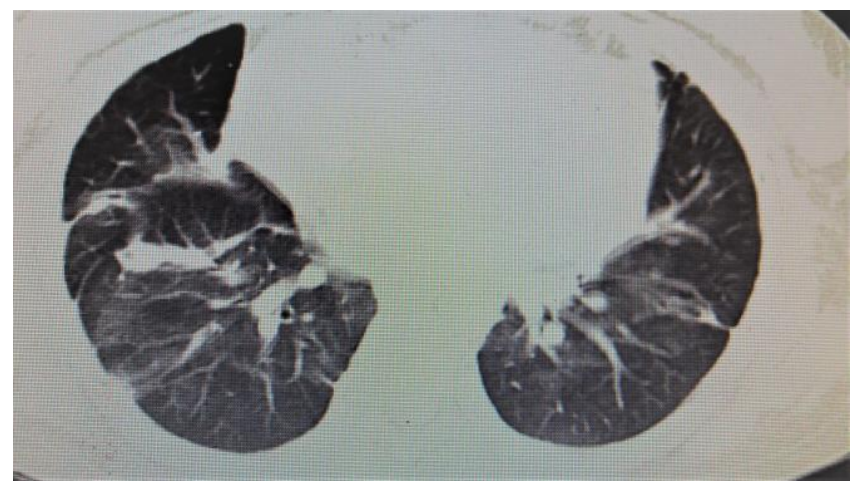

Figure 2a: CT scan of the thorax showed a ground-glass opacity appearance with traction bronchiectasis in bilateral lung fields

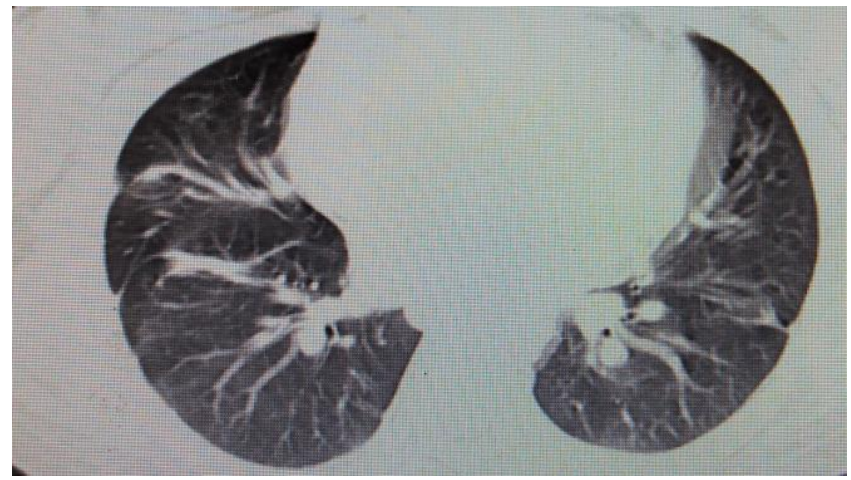

Figure $2 \mathrm{~b}$ : HRCT of the thorax after 6 months of treatment

\section{DISCUSSION}

SLE is a systemic autoimmune disorder that can involve the respiratory organs. Pulmonary complications of SLE can be divided into three types: infectious, malignant and disease-related. ILD is a disease-related complication related to SLE that may emerge as a complication of the disease itself, or from its treatment (1). The mechanism of ILD in most CTDs, including SLE, remains unclear, although it may be associated with the autoimmunity process, inflammation or vascular injury $(5,6)$.

Patients with ILD in CTD typically present with exertional dyspnea or chronic coughing (2). All patients with ILD should be question about the possibility of a known-cause ILD etiology in their clinical history, such as CTD symptoms, environmental exposure and medication toxicity. The CTD symptoms that should be explored including arthralgia, skin rash or photosensitivity $(2,7,8)$. In a physical examination, the physician may detect Velcro-like crackles upon pulmonary auscultation as a sign of ILD. The physician should also investigate extra-thoracic manifestations that may be related to CTD manifestations, such as Raynaud's phenomenon, mechanic's hands, puffy hands and malar rash, and others $(2,4,8)$. The results of laboratory tests, and in particular, autoimmune serology tests (ANA test, ds-DNA, and other autoantibody sero- logic tests) should be examined, as they may help in the diagnosis of the CTD type $(4,8,9)$. In our cases, the results are different from each other. In case 1, ILD was the first sign, appearing before the diagnosis of SLE was confirmed, while in case 2, ILD appeared after SLE had been diagnosed and treated. AFB smears were examined in both patients in these cases, given the high prevalence of TB in our country. The symptoms of pulmonary TB may resemble the features of ILD in CTD patients.

In addition to clinical history and the results of a physical examination, a diagnosis of ILD in CTD should also rely on chest imaging, and in particular, and HRCT of the chest. The most frequent pattern of ILD in CTD is NSIP, although other patterns may be encountered in this group, such as usual interstitial pneumonia (UIP), cryptogenic organizing pneumonia or lymphoid interstitial pneumonia $(2,9,10)$. A lung biopsy is optimum ILD diagnosis method, but it is not recommended in ILD-CTD cases, especially if an HRCT of the thorax shows the pattern of ILD clearly (9). Neither of our cases was subjected to a lung biopsy or bronchoscopy to establish the diagnosis, for this reason. Lung function tests in ILD patients may help to show the severity of the disease and can aid in monitoring progress. ILD patients will show impairment of FVC in a spirometry test and a reduction of the DLCO level (11). In case 1, the reduction of the DLCO level was severe, while in case 2 , we performed only a spirometry test, which showed the severe restriction. No measurement of DLCO was made prior to treatment in case 2 , as the device was unavailable at that time.

The management of ILD is still an experience-based rather than evidence-based practice. The treatment of patients with ILD-CTD requires an assessment of the symptoms, the severity of impairment in a lung function test or imaging, and the progressivity of the disease. Immunosuppressant drugs are a common form of ILD-CTD therapy, while corticosteroids are usually introduced earlier in a high dose to improve the symptoms and induce a response, after which, the CS dose will be tapered and until it reaches the maintenance dose, when a sparing agent will be added. The CS sparing immunosuppressive agents that may be used include cyclophosphamide, azathioprine or mycophenolate mofetil (MMF) $(12,13)$. A study by Fischer et al. of 125 patients with ILD-CTD found that MMF improved the percentage of FVC in 52, 104 and 156 weeks, and it was also found to enhance the percentage of DLCO in 52 and 104 weeks. Regarding the patterns identified in a chest HRCT, in subjects without a UIP pattern, the percentage of FVC and DLCO was im- 
proved, whereas in subjects with a UIP pattern, MMF stabilized the percentage of FVC and DLCO. It was also well-tolerated and had a low rate of discontinuation (14). Since ILD may develop in CTD patients, physicians should identify its occurrence when a diagnosis of CTD has been established, or when respiratory symptoms present in patients already diagnosed with CTD. Furthermore, screening for CTD should be a regular occurrence for patients diagnosed previously with ILD. The early detection of ILD-CTD patients may lead to the early application of appropriate treatments and an improved quality of life.

\section{CONFLICTS OF INTEREST}

None declared.

\section{AUTHOR CONTRIBUTIONS}

Concept - G.A., D.K.S., P.B.F.; Planning and Design G.A., D.K.S., P.B.F.; Supervision - G.A., D.K.S., P.B.F.; Funding - G.A., P.B.F.; Materials - G.A., P.B.F.; Data Collection and/or Processing - G.A., P.B.F.; Analysis and/or Interpretation - G.A., D.K.S., P.B.F.; Literature Review - G.A., D.K.S., P.B.F.; Writing - G.A., D.K.S., P.B.F.; Critical Review - G.A., D.K.S., P.B.F.

\section{YAZAR KATKILARI}

Fikir - G.A., D.K.S., P.B.F.; Tasarım ve Dizayn - G.A., D.K.S., P.B.F.; Denetleme - G.A., D.K.S., P.B.F.; Kaynaklar - G.A., P.B.F.; Malzemeler - G.A., P.B.F.; Veri Toplama ve/veya İşleme - G.A., P.B.F.; Analiz ve/veya Yorum G.A., D.K.S., P.B.F.; Literatür Taraması - G.A., D.K.S., P.B.F.; Yazıyı Yazan - G.A., D.K.S., P.B.F.; Eleştirel İnceleme - G.A., D.K.S., P.B.F

\section{REFERENCES}

1. Papiris SA, Manali ED, Kolilekas L, Kagouridis K, Maniati $M$, Borie $R$, et al. Investigation of lung involvement in connective tissue disorders. Respiration 2015; 90:2-24. [CrossRef]

2. Mittoo S, Fell CD. Pulmonary manifestations of systemic lupus erythematosus. Semin Respir Crit Care Med 2014; 35:249-54. [CrossRef]
3. Fischer A, Brown KK. Interstitial lung disease in undifferentiated forms of connective tissue disease. Arthritis Care Res (Hoboken) 2015; 67:4-11. [CrossRef]

4. $V_{i j} R$, Strek ME. Diagnosis and treatment of connective tissue disease-associated interstitial lung disease. Chest 2013; 143:814-24. [CrossRef]

5. Castelino FV, Varga J. Interstitial lung disease in connective tissue diseases: evolving concepts of pathogenesis and management. Arthritis Res Ther 2010; 12:213. [CrossRef]

6. Fong W, Yoong J. Interstitial lung disease and rheumatoid arthritis: a review. Proceed Singapore Healthcare 2015; 24:35-41. [CrossRef]

7. Demoruelle MK, Mittoo S, Solomon JJ. Connective tissue disease-related interstitial lung disease. Best Pract Res Clin Rheumatol 2016; 30:39-52. [CrossRef]

8. Antin-Ozerkis D, Rubinowitz A, Evans J, Homer RJ, Matthay RA. Interstitial lung disease in the connective tissue diseases. Clin Chest Med 2012; 33:123-49. [CrossRef]

9. Aparicio IJ, Lee JS. Connective tissue disease-associated interstitial lung diseases: unresolved issues. Semin Respir Crit Care Med 2016; 37:468-76. [CrossRef]

10. Henry TS, Little BP, Veeraraghavan S, Bhalla S, Elicker $B M$. The spectrum of interstitial lung disease in connective tissue disease. J Thorac Imaging 2016; 31:65-77. [CrossRef]

11. Lauretis A, Veeraraghavan S, Renzoni E. Connective tissue disease-associated interstitial lung disease: How does it differ from IPF? How should the clinical approach differ? Chronic Respiratory Disease 2011 ; 8:53-82. [CrossRef]

12. Lee JS, Fischer A. Current and emerging treatment options for interstitial lung disease in patients with rheumatic disease. Expert Rev Clin Immunol 2016; 12:509-20. [CrossRef]

13. Fischer $A$, du Bois R. Interstitial lung disease in connective tissue disorders. Lancet 2012; 380:689-98. [CrossRef]

14. Fischer A, Brown KK, Du Bois RM, Frankel SK, Cosgrove GP, Fernandez-Perez ER, et al. Mycophenolate mofetil improves lung function in connective tissue diseaseassociated interstitial lung disease. J Rheumatol 2013; 40(5):640-6. [CrossRef] 